\title{
Is there a role for cytokine-immune based therapy in HIV disease therapy?
}

\author{
Guido Poli \\ From $16^{\text {th }}$ International Symposium on HIV and Emerging Infectious Diseases \\ Marseille, France. 24-26 March 2010
}

\section{Background}

The partial capacity of HAART of reverting the immunological dysfunction associated with HIV-1 infection has stimulated the clinical investigation of cytokines as molecules endowed with strong immunological reconstitution potential.

\section{Methods}

Among other cytokines, cytokines utilizing a common $\gamma$ receptor chain for signal transduction (such as interleukin-2, IL-2, and IL-7) have been particularly studies for their high potential of boosting the adaptive immune response and of stimulating the proliferation of mature CD4+ and CD8+ T lymphocytes or of their precursors. In addition, GM-CSF, sharing some signaling pathways and clinical effects with IL-2 (i.e. boosting of $\mathrm{CD} 4^{+} \mathrm{T}$ cell counts), has also been studied. The recent failure of phase III trials on the use of intermittent IL-2 administration in spite of its proven effect of increasing CD4+ $\mathrm{T}$ cell counts poses the question of whether these approach maintain interest and rationale to be pursued in the context of successful HAART regimens.

\section{Results}

Clinical experimentations with IL-7 and GM-CSF are still ongoing and maintain promising potential. We have recently reported that intermittent IL-2 therapy counteracts the in vivo evolution of HIV-1 from CCR5 monotropic use to dualtropic (CCR5 and CXCR4) use (S. Ghezzi et al., HIV Medicine, 2009 Dec 8). IL-7 is also considered a powerful tool to purge viral reservoir embedded in resting memory CD4+ T cells. In this regard, most HIV+ individuals show the constitutive activation of a cleaved form of signal transducer and activator of transcription-5 (STAT5), commonly

\footnotetext{
Vita-Salute San Raffale University and San Raffaele Scientific Institute, Milano,
} Italy activated by IL-2, IL-7 and GM-CSF, therefore generating a transdominant negative inhibitor of STAT-5 dependent gene expression (A. Crotti et al., Blood, 2007).

\section{Conclusions}

Cytokines maintain their potential to complement HAART at least in those patients discordantly responding to antiretroviral agents. Furthermore, certain cytokines may be useful in the purge or attrition of viral reservoirs in the perspective of eradicating HIV infection.

Published: 11 May 2010

doi:10.1186/1742-4690-7-S1-I12

Cite this article as: Poli: Is there a role for cytokine-immune based therapy in HIV disease therapy? Retrovirology 2010 7(Suppl 1):112.
Submit your next manuscript to BioMed Central and take full advantage of:

- Convenient online submission

- Thorough peer review

- No space constraints or color figure charges

- Immediate publication on acceptance

- Inclusion in PubMed, CAS, Scopus and Google Scholar

- Research which is freely available for redistribution

Submit your manuscript at www.biomedcentral.com/submit
C Biomed Central 